\title{
Changes in the diet composition of Pygmy Cormorant Phalacrocorax pygmeus on Skadar lake (Southern Montenegro)
}

\section{Spremembe v prehrani pritlikavega kormorana Phalacrocorax pygmeus na Skadrskem jezeru (južna Črna gora)}

\author{
AndRej Vizi ${ }^{1} \&$ OndRej Vizi ${ }^{1}$ \\ ${ }^{1}$ Natural History Museum of Montenegro, Trg Bećir Bega Osmanagića 16, MN-81000 Podgorica, Montenegro, \\ e-mail: avizi@t-com.me,vizi@t-com.me
}

Diet changes of Pygmy Cormorant Phalacrocorax pygmeus, a piscivorous bird feeding primarily on fish up to $15 \mathrm{~cm}$ long, were studied on Skadar Lake. The breeding population on the lake was estimated at over 2,000 pairs in 2005 and 1,260 pairs in 2006 , comprising about $5-8 \%$ of the regional population of SE Europe \& Turkey. The first diet analysis, based on stomach contents of specimens hunted in the course of the breeding season, was carried out in the period 1973-1975 in order to identify the influence of the birds on commercial fishery. Further samples of regurgitated or accidentally dropped food items during the feeding of nestlings were collected and analyzed in the 2006 breeding season. Results from both periods are presented and changes in diet composition in the course of over 30 years are discussed. Between 1973-1975 and 2006, the Pygmy Cormorant's diet on Skadar Lake changed drastically. Only one fish species, Rudd Scardinius knezevici, was found to be common to both study periods. Pygmy Cormorant's diet in the period 1973-1975 consisted of 11 fish species ( $\mathrm{N}=224$ specimens), belonging to five families. The most abundant fish species were Roach Rutilus ohridanus and Albanian Roach Pachychilon pictum. Diet analysis in 2006 revealed only six species ( $\mathrm{N}=98$ specimens) from two families, and also showed that the introduced Goldfish Carassius auratus became a major food source for Pygmy Cormorant, constituting $84.7 \%$ of the total specimen number. Age class analysis of Goldfish items revealed that juvenile specimens $(45-90 \mathrm{~mm})$ comprised $89.0 \%$ of the total Goldfish compound. The study confirms that the Pygmy Cormorant is not a species-specific hunter and suggests it is not affected by the changes in composition of fish community in the littoral zone of the lake. Fish consumption by Pygmy Cormorants on Skadar Lake in 2006 was estimated at $45 \mathrm{t}$ during the most intensive foraging period (June-August).

Key words: Pygmy Cormorant, Phalacrocorax pygmeus, diet, Goldfish, Carassius auratus, Skadar Lake, Montenegro

Ključne besede: pritlikavi kormoran, Phalacrocorax pygmeus, Skadrsko jezero, prehrana, zlati koreselj, Carassius auratus, Črna gora

\section{Introduction}

Skadar Lake, with up to $540 \mathrm{~km}^{2}$ of water surface in the winter, is the largest lake of the Balkan Peninsula, situated between Montenegro (two thirds of the lake) and Albania (one third of the lake). The lake is a very important site for the breeding, wintering and passage of waterbirds. Up to 250,000 individuals of waterbirds winter on the lake (VAsIĆ et al. 1992). Skadar Lake supports one of the world's largest populations of Pygmy Cormorant Phalacrocorax pygmeus. The breeding population of this species on Skadar Lake was estimated at over 2,000 pairs in 2005 (SAVELJIĆ 2006) and 1,260 pairs in 2006 (VIZI 2009). These 
A. Vizi \& O. Vizi: Changes in the diet composition of Pygmy Cormorant Phalacrocorax pygmeus on Skadar lake (Southern Montenegro)

figures comprise about $5-8 \%$ of the regional population of SE Europe \& Turkey (DeLANY \& SCOTT 2006).

Data on the diet of Pygmy Cormorant are rather sparse (CRAMP 1998). The main diet comprises fish up to $15 \mathrm{~cm}$ long (Del Hoyo et al. I992, Cramp 1998), besides a small contribution of amphibians and insects (Platteeuw et al. 2004). In general, cormorants are notoriously recognized as a threat to fishery. However, research showed that Pygmy Cormorant poses no threat to commercial fish populations in Skadar Lake (VIZI I98I).

The first sampling and analysis of the Pygmy Cormorant's diet at Skadar Lake was performed by O. Vizi in the 1973-1975 period, but the results were not published. The analysis of these data and of new data collected during 2006 is presented here.

\section{Methods}

\subsection{Study area}

At Skadar Lake, Pygmy Cormorants breed in a single colony, at the locality called Crni Žar $\left(42^{\circ} 15^{\prime}\right.$ 23.18”N, 19¹8'58.37”E; UTM CM68) (Figure 1). It is a mixed-species colony, which includes three breeding species of herons and egrets - Squacco Heron Ardeola ralloides, Little Egret Egretta garzetta, and Night Heron Nycticorax nycticorax, as well as Glossy Ibis Plegadis falcinellus and Pygmy Cormorant.

The nests are completely mixed, which means that there are no distinguishable zones with different species. The very densely packed colony inhabits the bushes of Grey Willow Salix cinerea, Crack Willow Salix fragilis and Monk's Pepper Vitex agnus-castus, surrounded by vast fields of water lilies (Nymphaea alba, Nuphar luteum), Water Caltrop Trapa natans, Common Club-rush Schoenoplectus lacustris and Common Reed Phragmites australis (VIZI 1997B). The water in this locality is very shallow, warm and turbid, which, together with the dense vegetation, makes the colony very hard to reach.

The colony at Crni Žar was discovered in 1977, with the Cormorant Phalacrocorax carbo as the pioneer species. The first breeding of Pygmy Cormorant was confirmed in 1991, when the colony numbered about 600 nests (VIZI 1997A). However, although the location of Pygmy Cormorant's breeding site was unknown prior to 1991, they had certainly bred there well before. Šoti et al. (198I) claimed that, according to the species' daily movements and distribution on Skadar Lake, the colony must be located in the inaccessible area near the Albanian border. In 1992, Little Egret and Squacco Heron joined the colony, which has been growing ever since (VIZI 1997A).

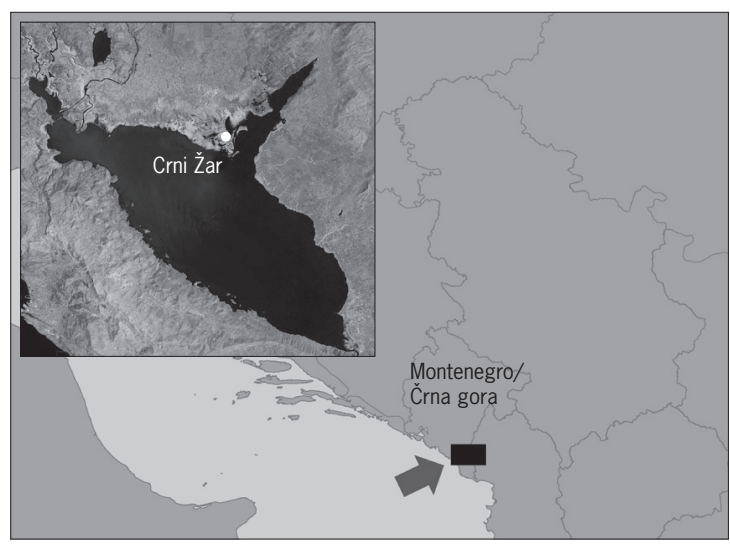

Figure 1: Position of the Pygmy Cormorant Phalacrocorax pygmeus colony at Skadar Lake (Southern Montenegro) (Adapted from NASA World Wind 2010)

Slika 1: Lega kolonije pritlikavega kormorana Phalacrocorax pygmeus na Skadrskem jezeru (južna Črna gora) (povzeto po NASA World Wind 2010)

\subsection{Materials and methods}

The first sampling of the Pygmy Cormorant's diet in the 1973-1975 period included stomach content analysis. These data are kept in the archive of the Natural History Museum of Montenegro. A total of 214 birds were hunted down, or obtained from hunters and fishermen in that period. Bird specimens were at that time mostly collected at the shallow localities of the northern swamp, which includes several freshwater tributaries. The birds were hunted down on their daily roosts and feeding sites. Each bird's stomach contents were separately extracted, drained, sorted and measured on an electronic scale with 0.1 g precision. The greater part of the stomach contents consisted of fish, with traces of herbal components and insects, all in different stages of digestion. Determination of fish remnants was accomplished on the basis of preserved morphological characters, to the lowest taxon possible, while other elements were omitted from further analysis. For the purpose of this research, we took into consideration only 64 birds, collected from April to August - the breeding period of the species (VIZI 1997A).

The diet analysis in 2006 was based on the collection of fish samples regurgitated or accidentally dropped during the feeding of nestlings. A total of 98 specimens were collected. Sampling was performed 
Table 1: Fish species and their abundance in Pygmy Cormorant Phalacrocorax pygmeus diet on Skadar Lake in the 19731975 period ( $N=64$ stomach contents)

Tabela 1: Vrste rib in njihova številčnost v prehrani pritlikavega kormorana Phalacrocorax pygmeus na Skadrskem jezeru v obdobju 1973-1975 ( $N=64$ vsebnosti želodca)

\begin{tabular}{llcc}
\hline Species / Vrsta & Family / Družina & $\begin{array}{c}\text { No. of specimens/ } \\
\text { Št. primerkov }\end{array}$ & Percentage / Odstotek (\%) \\
\hline Rutilus ohridanus & Cyprinidae & 76 & 33.9 \\
Pachychilon pictum & Cyprinidae & 52 & 23.2 \\
Blennius fluviatilis & Blenniidae & 26 & II.6 \\
Rhodeus amarus & Cyprinidae & 25 & II.2 \\
Cobitis ohridana & Cobitidae & 20 & 8.9 \\
Alburnus scoranza & Cyprinidae & $\mathrm{I} 3$ & 5.8 \\
Scardinius knezevici & Cyprinidae & 4 & $\mathrm{I} .8$ \\
Pomatoschistus montenegrensis & Gobiidae & 3 & $\mathrm{I} .3$ \\
Gobio scadrensis & Gobiidae & 2 & 0.9 \\
Gasterosteus gymnurus & Gasterosteidae & 2 & 0.9 \\
Squalius squalus & Cyprinidae & $\mathrm{I}$ & 0.4 \\
\hline Total / Skupaj & - & 224 & IOO.0 \\
\hline
\end{tabular}

twice, on 7 Jun 2006, at the beginning of the breeding

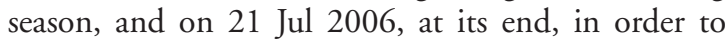
reduce disturbance impact. Samples were collected manually and fixed in 4\% formaldehyde. The standard length measurement (SL) and taxonomic determination was accomplished on the basis of preserved morphological characters, according to IVANOvić (I973) and Simonović (200I). The Goldfish Carassius auratus specimens were classified into two different age classes according to MARIć (I998).

Wet measured weight of stomach is a poor source for quantitative food intake estimation because diet items are greatly damaged by digestion. This also applies to regurgitated samples. Instead, we used the calculated value of daily fish intake, based on the birds' energy requirements. For the estimation of fish consumption by Pygmy Cormorants, we used the value of daily fish intake of $200 \mathrm{~g}$, calculated during a similar research at the Danube delta. The equation took into consideration the allometric relationship between body mass, caloric value of fish flesh and assimilation efficiency in piscivorous birds (PlatTEEUW et al. 2004).

\section{Results}

\subsection{Pygmy Cormorant's diet in the 1973-1975 period}

A total of 11 fish species belonging to five families were found in the Pygmy Cormorant's diet, based on samples from the 1973-1975 period. The most abundant were Roach Rutilus ohridanus, Albanian Roach Pachychilon pictum, Freshwater Blenny Blennius fluviatilis, and European Bitterling Rhodeus amarus, all of them exceeding $10 \%$ of the total number of specimens in the samples (Table 1).

The mean weight of stomach contents measured in the wet state ranged from 28.2 to $59.4 \mathrm{~g}$ per month and showed a statistically marginally significant increase in food consumption (linear slope $>0 ; \mathrm{P}=$ 0.0967) from April to August, which corresponds to the Pygmy Cormorant's breeding period (Figure 2).

\subsection{Pygmy Cormorant's diet in 2006}

Of a total of 98 fish specimens collected in 2006, 83 belonged to Goldfish. This species comprised $84.7 \%$ of all prey items taken by Pygmy Cormorants. Five other fish species were found in only low quantities $(<10 \%)$. The results of the taxonomic analysis of all collected fish specimens are presented in Table 2 .

Age class analysis of Goldfish shows that Pygmy Cormorant consumed mostly immature specimens of the class $0^{+}$(younger than one year), and occasionally $1^{+}$ (between one and two years). No older specimens were found in the sample. Juvenile specimens belonging to the class $0^{+}(45-90 \mathrm{~mm})$ comprised $89.0 \%$ of total Goldfish compound.

Based on the daily fish intake of $200 \mathrm{~g}$ and population figures for 2006, it can be estimated that the current Pygmy Cormorant population on Skadar 
A. VIZI \& O. VIzI: Changes in the diet composition of Pygmy Cormorant Phalacrocorax pygmeus on Skadar lake (Southern Montenegro)

Table 2: Fish species and their abundance in Pygmy Cormorant Phalacrocorax pygmeus diet on Skadar Lake during the 2006 breeding season ( $N=98$ fish samples collected in the colony)

Tabela 2: Vrste rib in njihova številčnost v prehrani pritlikavega kormorana Phalacrocorax pygmeus na Skadrskem jezeru v gnezditvenem obdobju 2006 ( $N$ = 98 ribjih primerkov, zbranih v koloniji)

\begin{tabular}{lccc}
\hline Species / Vrsta & Family / Družina & $\begin{array}{c}\text { No. of specimens/ } \\
\text { St. primerkov }\end{array}$ & Percentage / Odstotek (\%) \\
\hline Carassius auratus & Cyprinidae & 83 & 84.7 \\
Pseudorasbora parva & Cyprinidae & 6 & $6 . \mathrm{I}$ \\
Cyprinus carpio & Cyprinidae & 5 & $5 . \mathrm{I}$ \\
Perca fluviatilis & Percidae & 2 & 2.0 \\
Barbus rebeli & Cyprinidae & $\mathrm{I}$ & I.O \\
Scardinius knezevici & Cyprinidae & $\mathrm{I}$ & I.O \\
\hline Total / Skupaj & - & 98 & I0०.0 \\
\hline
\end{tabular}

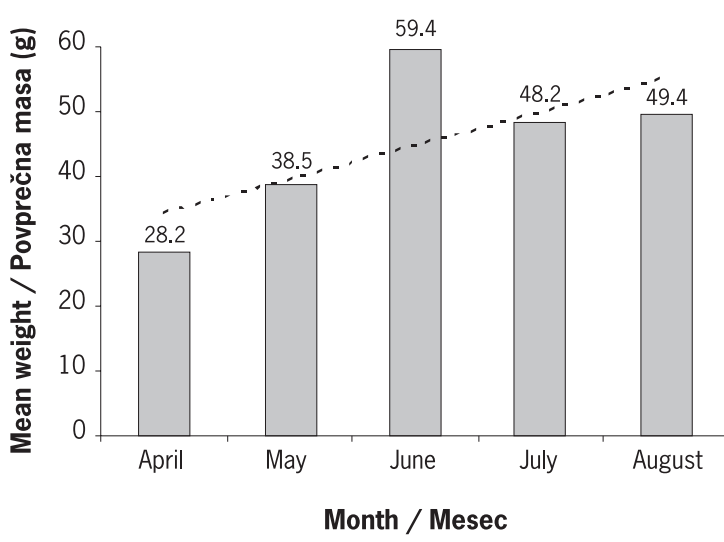

Figure 2: Mean weight of the wet stomach contents of Pygmy Cormorant Phalacrocorax pygmeus $(\mathrm{N}=64)$ collected on Skadar Lake from April to August in the 1973 -1975 period (linear slope $>0, P=0.0967$ )

Slika 2: Povprečna mokra masa vsebnosti v želodcih pritlikavega kormorana Phalacrocorax pygmeus ( $N=64)$, zbranih na Skadrskem jezeru med aprilom in avgustom v obdobju 1973-1975 (linearni naklon > 0, P = 0,0967)

Lake consumes about $500 \mathrm{~kg}$ of fish per day during the breeding season. During the most intensive foraging period, from the beginning of June to the end of August, fish consumption can be roughly calculated to $45 \mathrm{t}$ of fish. According to the abundance of prey items in 2006, about $34 \mathrm{t}$ were Goldfish juveniles.

\section{Discussion}

Pygmy Cormorant's diet on Skadar Lake has changed drastically over the last 30 years. Only one fish species, Rudd Scardinius knezevici, was found as the diet component in both periods of our study. A number of species that used to be common in Pygmy Cormorant's diet during 1973-1975 were missing in 2006, e.g. Bleak Alburnus scoranza, European Bitterling, Freshwater Blenny and especially two most numerous species, Roach Rutilus obridanus and Albanian Roach. On the other hand, four new prey items were found in 2006 sampling, including the most abundant Goldfish, as well as two other introduced species, European Perch Perca fluviatilis and Topmouth Gudgeon Pseudorasbora parva. The finding of recently introduced fish species in the diet confirms that Pygmy Cormorant is not a speciesspecific hunter. Similar diet research in the Danube delta (Platteeuw et al. 2004) found it to forage on 15 fish species, including European Perch, Carp Cyprinus carpio, Common Rudd Scardinius erythrophthalmus, Goldfish and Roach Rutilus obridanus, together with ten other species not present in Skadar Lake.

Despite the relatively small sample size, it can be concluded that Goldfish became the major prey item of Pygmy Cormorant. Goldfish is believed to have been introduced intentionally to Skadar Lake in the 1970s, since the first catch occurred in 1973 (MARIĆ 1995). Similarly, European Perch and Topmouth Gudgeon appeared in Skadar Lake in the late 1970s (Marić \& KrIVOKapić 1997), and have adapted successfully ever since. In the light of the much more varied diet in 1973-1975, this fact suggests that Pygmy Cormorant is not affected by the changes in composition of the fish community. Being a nonspecific fish eater, Pygmy Cormorant diet reflects the composition of fish populations in the lake's littoral zone. The prevalence of Goldfish based on samples from 2006 can be interpreted in terms of its ecological traits. Most fish species start their reproduction in spring, 
from March to June, depending on water temperature (Janković I97I, Ivanović I973 \& KNeŽEvić I984). The Goldfish reproductive period spans the warm part of the year because its reproductive cycle can be triggered by seven other species of cyprinid fish (Marić 1998). This means that Goldfish is the most abundant in the shallow littoral zone where spawning takes place, and therefore heavily exploited by Pygmy Cormorants, which are known to hunt in shallow waters (CRAMP 1998, own data). The presence of species like Freshwater Blenny and European Bitterling in the 1970s research confirms the Pygmy Cormorant to be a littoral hunter, since these fish species inhabit small freshwater streams in the shallow northern part of the lake. The most abundant fish in Skadar Lake at the time, Bleak Alburnus scoranza, did not equally feature in the diet owing to its dispersion in the pelagial zone of the lake during the birds' breeding season (IvanOvić 1968, this study). Adult Pygmy Cormorants are observed hunting all over the littoral zone of Skadar Lake during the breeding season (VIZI \& DUbaK 2008), which confirms not only that regurgitated samples do not necessarily origin from the colony or adjacent localities, but also that changes in the composition of fish community occurred throughout the littoral zone.

The Pygmy Cormorant's breeding period corresponds to the spawning period of Skadar Lake fishes. They start building nests there in April and to lay eggs in June (VIZI 1997A). The incubation period is 27-30 days (CrAmp 1998), which suggests that the period of intensive feeding of the nestlings begins in July and lasts till the end of August (VIzI I997A). In 2006, most of the samples were collected during the first visit on 7 Jun. The second visit, on 21 Jul, yielded only few samples, suggesting that Pygmy Cormorant had already passed the peak of the breeding season. However, a number of nests at the colony still contained young nestlings and un-hatched eggs. In general, this is consistent with the increase in the stomach contents' mean weight in the latter part of the breeding season.

The annual catch of Goldfish is roughly estimated at over 200 t (MARIć 1995), based on the obsolete commercial catch statistics. Pygmy Cormorant's consumption of this fish during the breeding season, calculated from its energy requirements, amounts to $38 \mathrm{t}$. Another fact that excludes the suggestion of competition with fishermen on Skadar Lake is that Pygmy Cormorant forages mostly on immature specimens, which are not being caught by fishing gear as being undersized and inaccessible swamp dwellers. The research proves that Pygmy Cormorant apparently hunts the most abundant species in the littoral zone of the lake, which is generally beneficial for the lake ecosystem. Due to the fact that, as a piscivorous bird, it occupies a high trophic level in the food chain, its diet changes indicate deep and comprehensive changes in the ecosystem of Skadar Lake, which need to be investigated separately.

\section{Povzetek}

Avtorja članka sta na Skadrskem jezeru preučevala spremembe $\mathrm{v}$ prehrani pritlikavega kormorana Phalacrocorax pygmeus, ribojede vrste, ki izbira predvsem med ribami, dolgimi do $15 \mathrm{~cm}$. Ob jezeru gnezdeča kolonija je bila leta 2005 ocenjena na več kot 2.000 parov, leta 2006 pa na 1.260 parov, kar je pomenilo $5-8 \%$ regionalne populacije te vrste $\mathrm{v} J \mathrm{~J}$ Evropi in Turčiji. Prva analiza prehrane, temelječa na vsebnostih $\mathrm{v}$ želodcih pritlikavih kormoranov, ulovljenih $\mathrm{v}$ gnezditveni sezoni, je bila opravljena $\mathrm{v}$ obdobju 1973-1975, in sicer kot poskus, da se ugotovi vpliv teh ptic na lokalno ribištvo. $\mathrm{V}$ gnezditveni sezoni 2006 so bili zbrani in analizirani vzorci plena, izbljuvani ali po nesreči spuščeni med hranjenjem mladičev $\mathrm{v}$ gnezdih. Članek predstavlja rezultate, dobljene za obe obdobji, in razpravlja o spremembah v sestavi prehrane v zadnjih tridesetih letih. Najpomembnejša ugotovitev je, da se je med obdobjem 1973-1975 in letom 2006 prehrana pritlikavega kormorana na Skadrskem jezeru drastično spremenila. Le ena ribja vrsta, rdečeperki sorodna Scardinius knezevici, je bila v prehrani najdena v obeh preučevanih obdobjih. Prehrana pritlikavega kormorana v obdobju 1973-1975 je obsegala 11 ribjih vrst $(\mathrm{N}=224$ primerkov), pripadajočih petim družinam. Najštevilčnejši med njimi sta bili Rutilus ohridanus in Pachychilon pictum. Analiza prehrane leta 2006 pa je razkrila, da vsebuje samo šest ribjih vrst $(\mathrm{N}=$ 98 primerkov) iz dveh družin in da je v jezeru naseljeni zlati koreselj Carassius auratus postal glavni vir hrane pritlikavega kormorana, saj je sestavljal kar $84,7 \%$ vseh primerkov. Analiza starostnega razreda zlatega koreslja je pokazala, da mladi primerki ( $45-90 \mathrm{~mm}$ ) sestavljajo $89,0 \%$ skupne količine te ribje vrste. Študija je hkrati potrdila, da pritlikavi kormoran ni vrstno specifičen plenilec in da ga niso prizadele spremembe v sestavi ribje združbe v obrežnem pasu jezera. Avtorja ocenjujeta, da so leta 2006, v obdobju najbolj intenzivnega hranjenja (junij-avgust), pritlikavi kormorani v Skadrskem jezeru pojedli $45 \mathrm{t}$ rib. 
A. Vizi \& O. VIzI: Changes in the diet composition of Pygmy Cormorant Phalacrocorax pygmeus on Skadar lake (Southern Montenegro)

\section{References}

Cramp, S. (ed.) (I998): The Complete Birds of The Western Palearctic on CD-ROM. - Oxford University Press, Oxford.

del Hoyo, J., Elliott, A. \& Sargatal, J. (eds.) (I992): Handbook of the Birds of the World. Vol. 1. Ostrich to Ducks. - Lynx Edicions, Barcelona.

Delany, S \& Scott, D. (2006): Waterbirds Populations Estimates. Fourth Edition. - Wetlands International, Wageningen.

Ivanović, B. (1968): Ekologija Alburnus albidus alborella (Filippi). - Godišnjak Biološkog Univerziteta u Sarajevu 21: 5-70.

Ivanović, B. (I973): Ichthyofauna of Skadar Lake. Institution of medical and biological research in Montenegro, Biological station, Titograd.

Janković, D. (I97I): Razmnožavanje šarana (Cyprinus carpio L.) iz Skadarskog jezera. - Arhiv bioloških nauka / Archives des sciences biologiques 23 (1/2): 63-84.

KneŽević, B. (1984): Ekologija Scardinius erythrophthalmus scardafa (Bonaparte, 1832) Skadarskog jezera. Doktorska disertacija, Univerzitet u Sarajevu, Prirodnomatematički fakultet.

Marić, D. (I995): Rasprostranjenje i brojnost introdukovanog srebrnog karaša (Carassius gibelio, Bloch 1782) u Skadarskom jezeru u periodu 1972/92. - Glasnik Republičkog zavoda za zaštitu prirode u Podgorici 27/28: 113-127.

MArić, D. (I998): Adaptacija introdukovanog srebrnog karaša (Carassius auratus gibelio, Bloch 1782) na Skadarskom jezeru. - Doktorska disertacija, Univerzitet u Kragujevcu, Prirodno-matematički fakultet, Instutut za biologiju.

Marić, D. \& Krivokapić, M. (I997): Stanje faune riba u slivu Skadarskog jezera. pp. 215-223 In: MıjušKović, M. (ed.): Prirodne vrijednosti i zaštita Skadarskog jezera: radovi sa naučnog skupa, knjiga 44. - Crnogorska akademija nauka i umjetnosti, Podgorica.

Platteeuw, M., Kiss, J.B., Zhmud M.Y. \& Sadoull, N. (2004): Colonial Waterbirds and Their Habitat Use in the Danube Delta, as an example of a large-scale natural wetland. RIZA Report 2004. - Institute for Inland Water Management and Waste Water Treatment RIZA, Lalzstad; Danube Delta National Institute, Tulcea; Danube Delta Biosphere Reserve, Vilkove \& Tour du Valat, Arles.

SAVELjIĆ, D. (2006): The Breeding of Pygmy Cormorant Phalacrocorax pygmeus in Montenegro: a review. Acrocephalus 27 (130/131): 123-129.

Simonović, P. (200I): Ribe Srbije. - NNK International, Zavod za zaštitu prirode Srbije \& Biološki fakultet Univerziteta u Beogradu, Beograd.

Šoti, J., Vizi, O. \& Krsmanović, L. (I98I): Težina i mere malog kormorana, Phalacrocorax pygmaeus (Pallas), 1773 sa Skadarskog jezera (Jugoslavija). - Glasnik Republičkog zavoda za zaštitu prirode i Prirodnjačkog Muzeja Titograd 14: 53-62.
Vasić, V., Puzović, S. \& Vizi, O. (I992): Capacities Of Lake Skadar in Relation to European Regional Populations Of Water Birds. - Glasnik Republičkog zavoda za zaštitu prirode i Prirodnjačkog Muzeja Podgorica 25: 53-62.

VIzI, A. (2009): Uticaj ptica iz reda Pelecaniformes tokom perioda gniježđenja na faunu riba Skadarskog jezera. - Magistarski rad, Prirodno-matematički fakultet, Univerzitet Crne Gore, Podgorica.

VizI, O. (I98I): Some aspects of relationships between the fish populations and populations of swamp birds at Lake Skadar. pp. 414-419 In: Karaman, G.S. \& BeEton, A.M. (eds.): The Biota and Limnology of Lake Skadar. - Institution of medical and biological research in Montenegro, Biological station, Titograd.

VIZI, O. (I997A): Crni žar - nova kolonija močvarnih ptica na Skadarskom jezeru. pp. 309-320 In: MijušKović, $M$. (ed.): Prirodne vrijednosti i zaštita Skadarskog jezera: radovi sa naučnog skupa, knjiga 44. - Crnogorska akademija nauka i umjetnosti, Podgorica.

VIZI, O. (I997B): Neki efekti eutrofizacije Skadarskog jezera na primjeru makrofitske vegetacije. pp. 299-308 In: MrjušKović, M. (ed.): Prirodne vrijednosti i zaštita Skadarskog jezera: radovi sa naučnog skupa, knjiga 44. Crnogorska akademija nauka i umjetnosti, Podgorica.

Vizi, O. \& Dubak, N. (2008) Izvještaj o rezultatima monitoringa vodenih ptica - gnjezdarica u NP Skadarsko jezero u 2008. godini. - JP za Nacionalne parkove Crne Gore, Podgorica.

Arrived / Prispelo: 6.3.2008

Accepted / Sprejeto: 15.10.2010 